\title{
Integrated Effect of Inorganic and Organic Nitrogen Sources on Growth and Yield of Roselle (Hibiscus sabdariffa L.)
}

\author{
Al- Sayed, H.M.; S.A. Hegab; M.A. Youssef and M.Y. Khalafalla
}

Soils and Water Dept., Fac. of Agric., Al-Azhar Univ., Assiut, Egypt.

\begin{abstract}
The pot experiment was conducted in summer season of 2017 at Assiut Governorate, Egypt, to study the influence of compost and different rates of inorganic nitrogen on growth and chemical composition roselle as well as yield. The studied treatments include the application of recommended dose of $\mathrm{N}$ as $\mathrm{T}_{1}=$ urea, $\mathrm{T}_{2}=$ compost, $\mathrm{T}_{3}=75 \%$ urea $+25 \%$ compost and $\mathrm{T}_{4}=50 \%$ urea $+50 \%$ compost. Plants treated with the combination of mineral nitrogen and organic fertilization gave the highest significant values of growth parameters, i.e., plant height, as well as fresh and dry weight of leaves, chlorophyll, carotenoids, N, P and $\mathrm{K}$ contents in leaves tissues. While the application of full dose in the inorganic form gave the moderate values compared to the untreated plant. The maximum sepals yield was obtained from the $100 \%$ of $\mathrm{N}$ from compost treatment which increased the fresh and dry weight of sepals by 228.75 and $138.96 \%$ above the un-treated soil. Generally it is concluded that roselle sepals yield and quality can be improved through the treatment of $100 \%$ composted and application of $50 \%$ urea $+50 \%$ compost improved the growth and yield of roselle also increased the available $\mathrm{N}$ nutrients in the soil as well as the macronutrients concentrations. Therefore, this treatment could be recommended to obtain economical yield with satisfactory quality and to improve the soil fertility under the conditions of the studied area.
\end{abstract}

Keywords: Urea, compost, sepals, chlorophyll, carotenoids.

\section{Introduction}

Medicinal plants are used throughout the world, and the regulations defining their proper use, such as identification of the correct species and page verification of the presence, purity and concentration of the required chemical compounds, are widely recognized (Palhares, et al., 2015). The global market of herbal medicines products is estimated at $\$ 83$ billion US and continues to grow (WHO, 2011). Medicinal plants considered among the promising crops which can increase Egypt income from foreign currency (Mohamed, 2012). However, the value of its exports is estimated at about $6.6 \%$ of the total value of the Egyptian agricultural exports representing around $0.39 \%$ of the total crop-area. Egypt has a lot of ingredients that help medical and aromatic plants to be flourished, such as climate and the availability of productive factors such as manpower, proper soil and availability of reclaimed land areas (Mostafa, 2016). The roselle plant is one of the most important medical and aromatic plants in Egypt (Mohamed, 2012; Mostafa, 2016).

\section{Roselle (Hibiscus sabdariffa} L.), family Malvaceae, is known commonly as Karkade. It is also known under other different names in different countries viz roselle, razelle, 
sorrel, red sorrel, Jamaica sorrel, Indian sorrel, Guinea sorrel, sour-sour, and queens land jelly plant (Moroton, 1987). It is an important crop in tropical and sub-tropical regions (El Naim et al., 2017). The roselle plant can be found in almost all warm countries such as India, Saudi Arabia, Malaysia, Indonesia, Thailand, Philippines, Vietnam, Sudan, Egypt and Mexico (Rao, 1996 and Chewonarin et al., 1999). Roselle is mainly cultivated to be consumed and the main producers of roselle blossoms are Egypt, Sudan, Mexico, Thailand and China (Naturland, 2004).

Organic amendments hold great promise as an excellent source of both macro and micro nutrients. Organic manures provide organic acids which help in dissolving soil nutrients and make in available for plants (Rajasekaran et al., 2015; Mondal et al., 2015; Sharma and Chaubey, 2015; Saeed et al., 2015). Chemical fertilizers are expensive and due to low purchasing power of farmers, particularly in developing countries, farmers cannot apply fertilizers in balanced proportion, which resulted in low yield (Ahmad, 1999). Under such condition, integrated use of chemical and organic $\mathrm{N}$ sources can play an important role to sustain soil fertility and crop yield (Tandon, 1998; Lampe, 2000).

Organic amendments besides supplying chemical fertilizer to the current crop, often leaves important part as residual effect on the succeeding crops in the system (Gaur, 1982). Nitrogen applied to previous crop had a remarkable effect on yield, fertilizer use efficiency and soil fertility. It is important that residual value of fertil- izer nitrogen should be taken into account when applying fertilizer $\mathrm{N}$ to the succeeding crop (Shafi et al., 2012).

This study is guidance for studying the effect of inorganic and organic $\mathrm{N}$ combination on vegetative aspects, sepal yield and yield components of roselle plant.

\section{Materials and Methods \\ Pot Experiment}

Soil sample $(0-30 \mathrm{~cm})$ was collected from the Agricultural Experimental Farm of the Faculty of Agriculture, AL-Azhar University, Assiut, Egypt, which is located at $27^{\circ} 12^{-}$ $16.67^{\circ} \mathrm{N}$ latitude and $31^{\circ} 09^{-} 36.86^{\circ}$ E longitude in 2017. The collected soil sample was sieved to pass through a $2 \mathrm{~mm}$ stainless steel sieve. Plastic pots, $40 \times 40 \mathrm{~cm}$, were filled with $20 \mathrm{~kg}$ of the studied soil. The current trail aims to investigate the response of roselle plants to a organic manure, mineral fertilizer and combination between organic and mineral fertilizer. Roselle (Hibiscus sabdariffa L.cv. Sabhia 17) seeds (obtained from the Horticultural Research Institute, Agricultural Research Center, Ministry of Agriculture, Giza, Egypt). Five seeds of roselle were sown in each pot on $15^{\text {th }}$ April 2017 and after emergence the number of plants was thinned to two plants per pot. The plants were irrigated regularly to keep the soil moisture content near field capacity. The treatments are as follows: $\mathrm{C}$ without fertilizer, $\mathrm{T}_{1}=100 \%$ of recommendation does from urea $(46.5 \% \mathrm{~N})$ at rate of $0.16 \mathrm{~g} / \mathrm{kg}$ soil, $\mathrm{T}_{2}=100 \%$ compost $(1.2 \% \mathrm{~N})$ at rate of $5.83 \mathrm{~g} / \mathrm{kg}$ soil, $\mathrm{T}_{3}=75 \%$ urea +25 $\%$ compost $(0.12+1.46 \mathrm{~g} / \mathrm{kg}$ soil $)$ and $\mathrm{T}_{4}=50 \%$ urea $+50 \%$ compost 
$(0.08+2.92 \mathrm{~g} / \mathrm{kg}$ soil $)$. Calcium superphosphate $\left(15.5 \% \mathrm{P}_{2} \mathrm{O}_{5}\right)$ at rate of 0.2 $\mathrm{g} / \mathrm{kg}$ soil and potassium sulphate $\left(48 \% \mathrm{~K}_{2} \mathrm{O}\right)$ at rate of $0.075 \mathrm{~g} / \mathrm{kg}$ soil was added to the soil. The rate of mineral fertilization was added according to the Egyptian Ministry of Agriculture and Land Reclamation. However, P-fertilizer and organic fertilizer were added to the pots before the sowing and during soil preparation. Plant samples were collected at full blooming stage $\left(26^{\text {th }}\right.$ August $2017)$ and at harvest stage $\left(25^{\text {th }}\right.$ October 2017) and the plant growth parameters i.e., plant height, number of branches per plant, number of sepals per plant, fresh and dry weight of plant were recorded. All the collected samples were cleaned, washed with tap and distilled water, air dried, and then dried in oven at $70^{\circ} \mathrm{C}$ until constant weight, ground and stored for chemical analysis. Representative dry samples were taken from each replicate for chemical analysis.

\section{Analysis of physiochemical proper- ties of the studied soil}

Data in Table 1 and 2 shows some physical and chemical properties of the soil $(0-30 \mathrm{~cm}$ depth) used in the experiment before swoing and some chemical characteristics of tested organic waste, receptivity. Particle-size distribution was carried out using the pipette method according to (Jackson, 1973). The pH of soil was measured in (1:2.5soil: water suspension) and the electrical conductivity (EC) was measured in (1:2.5) and (1:5) extracts in soil and organic waste, receptivity (Jackson, 1973). Soil organic matter was determined by wet oxidation method by $\mathrm{K}_{2} \mathrm{Cr}_{2} \mathrm{O}_{7}$ $1 \mathrm{~N}$ and $\mathrm{H}_{2} \mathrm{SO}_{4}$ (Baruah and Bartha- kur, 1997). Available nitrogen was extracted with $1 \% \mathrm{~K}_{2} \mathrm{SO}_{4}$ at a ratio of $1: 5$. Then, $20 \mathrm{ml}$ of the extract were distilled with the addition of $1 \mathrm{~g}$ Devarda's alloy using a micro Kjeldahl's distilling unit into a flask containing $10 \mathrm{ml}$ boric acid-mixed indicator solution until about $50 \mathrm{ml}$ distillate in each flask was collected. After the distillation, available nitrogen $\left(\mathrm{NH}_{4}{ }^{+}+\mathrm{NO}_{3}{ }^{-}\right)$content was determined in the distillate by titrating with standardized $0.01 \mathrm{~N}$ sulphuric acid (Jackson, 1973). The available soil phosphorus was extracted from 5 $\mathrm{g}$ of soil sample using $100 \mathrm{ml}$ of Na$\mathrm{HCO}_{3}$ method buffered at $\mathrm{pH} 8.5$ according to Olsen et al. (1954). Phosphorus in the extract was determined using the phosphomolybdic acid and stannous chloride method and measured by spectrophotometer at $660 \mathrm{~nm}$ (Jackson, 1973). The available soil potassium was extracted from $5 \mathrm{~g}$ of soil sample using $50 \mathrm{ml}$ by ammonium acetate $1 \mathrm{M}$ at $\mathrm{pH} 7.0$ and measured by flame photometer (Jackson, 1973). Total nitrogen was measured in soil samples by digestion using $20 \mathrm{ml}$ of a mixture of 7: 3 ratio of sulfuric to perchloric acids, then $5 \mathrm{ml}$ of digested sample were distilled with $20 \mathrm{ml}$ of $40 \%$ sodium hydroxide using a micro Kjeldahl's distilling unit into an Erlenmeyer flask containing $10 \mathrm{ml}$ boric acid-mixed indicator solution until about $50 \mathrm{ml}$ distillate in each flask was collected. After distillation, total nitrogen content was determined in the distillate by titrating with a standardized $0.01 \mathrm{~N}$ sulphuric acid (Jackson, 1973). Total phosphorus was measured in the soil samples by digestion using $20 \mathrm{ml}$ of a mixture of 7: 3 ratio of sulfuric to perchloric 
acids. Total calcium carbonate was determined by Collin's calcimeter according to Nelson, 1982. The values of field capacity and permanent wilting point (PWP) were determined using the pressure cooker and pressure membrane apparatus. A saturated undisturbed and disturbed soil samples were equilibrated at suction pressures of 0.33 and 15 bar, respectively, according to Shawky, 1967.

Table 1. Some physical and chemical properties of representative soil sample (0-30 cm depth) before sowing

\begin{tabular}{|l|c|c|}
\hline \multicolumn{1}{|c|}{ Properties } & Unit & $\mathbf{0 - 3 0 ~ c m}$ \\
\hline Sand & $\%$ & 53.5 \\
\hline Silt & $\%$ & 22.3 \\
\hline Clay & $\%$ & 24.2 \\
\hline Texture & & Sandy clay loam \\
\hline Field capacity & $\mathrm{v} \%$ & 30 \\
\hline Witling point & $\mathrm{v} \%$ & 21.6 \\
\hline CaCO & $\%$ & 1.5 \\
\hline pH (1:2.5 suspension) & & 8.14 \\
\hline EC (1:2.5 extract) & $\mathrm{dS} \mathrm{m}^{-1}$ & 0.92 \\
\hline Organic matter & $\mathrm{g} \mathrm{kg}^{-1}$ & 6.0 \\
\hline Total N & $\mathrm{mg} \mathrm{kg}^{-1}$ & 1000 \\
\hline Total P & $\mathrm{mg} \mathrm{kg}^{-1}$ & 300 \\
\hline Total K & $\mathrm{mg} \mathrm{kg}^{-1}$ & 400 \\
\hline Available N & $\mathrm{mg} \mathrm{kg}^{-1}$ & 55 \\
\hline Available Olsen P & $\mathrm{mg} \mathrm{kg}^{-1}$ & 8.5 \\
\hline Available K & $\mathrm{mg} \mathrm{kg}^{-1}$ & 98.5 \\
\hline
\end{tabular}

Each value represents a mean of three replicates.

Table 2. Some chemical characteristics of tested organic waste

\begin{tabular}{|l|c|c|}
\hline \multicolumn{1}{|c|}{ Properties } & Unit & Compost \\
\hline $\mathrm{pH}(1: 2.5$ suspension) & & 7.5 \\
\hline $\mathrm{EC}(1: 5$ extract $)$ & $\mathrm{dS} \mathrm{m}^{-1}$ & 5.9 \\
\hline Organic matter & $\mathrm{g} \mathrm{kg}^{-1}$ & 330 \\
\hline Total $\mathrm{N}$ & $\mathrm{mg} \mathrm{kg}^{-1}$ & 12000 \\
\hline Total $\mathrm{P}$ & $\mathrm{mg} \mathrm{kg}^{-1}$ & 7000 \\
\hline Total $\mathrm{K}$ & $\mathrm{mg} \mathrm{kg}^{-1}$ & 8700 \\
\hline
\end{tabular}

Each value represents a mean of three replicates.

\section{Plant sample analysis}

Plant samples were taken and washed with deionized water, ovendried at $70^{\circ} \mathrm{C}$, mill ground and kept for chemical analysis. Dried grounded plant material of $0.2 \mathrm{~g}$ was digested using $10 \mathrm{ml}$ of a mixture of 7: 3 ratio of sulfuric to perchloric acids (Jackson, 1973). Total nitrogen was measured in the digested sample by distilled with $20 \mathrm{ml}$ of $40 \%$ sodium hydroxide using a micro Kjeldahl's distilling unit (Jackson, 1973). Total phosphorus was measured in the extract by using the chlorostannous, ammonium -molybdate method while $\mathrm{K}$ was measured in the extract by using flame photometer (Jackson, 1973). 
The photosynthetic pigments; chlorophyll a (Chl-a), chlorophyll b (Chl-b), total chlorophyll $(\mathrm{Chl} \mathrm{a}+\mathrm{b})$, and carotenoid contents were assessed following the modified protocol of Lichtenthaler (1987). Briefly, $100 \mathrm{mg}$ of fully expanded fresh leaf was extracted with $10 \mathrm{ml}$ ethyl alcohol $(95 \%)$ in a test tube and kept in darkness until the sample's color was completely turned into white. Chl-a and Chl-b concentrations were measured by spectrophotometer at 663 and $644 \mathrm{~nm}$, respectively. Carotenoid concentration was also determined spectrophotometrically using the same plant extract at $452 \mathrm{~nm}$. The blank was $95 \%$ ethyl alcohol.

Total anthocyanin (TAC) and total flavonel (TF) were extracted from $1 \mathrm{~g}$ of the dried sepals by adding $10 \mathrm{ml}$ of 85:15 ratio of ethanol (97\%) and $\mathrm{HCl} 1.5 \mathrm{M}$. Then the sample was transferred to $50 \mathrm{ml}$ beaker, covered and kept overnight in the refrigerator at temperature of $4 \mathrm{C}^{\mathrm{o}}$. The solutions were made up to $50 \mathrm{ml}$. Absorption of solution was measured by spectrophotometer at wavelength $535 \mathrm{~nm}$ for TAC and $374 \mathrm{~nm}$ for TF. The method was modified by Lee and Francis (1971).

TAC $(\mathrm{mg} / 100 \mathrm{~g}$ dry weight $)=$ $(\mathrm{A} 535 \times \mathrm{V} \times 100) /(98.2 \times \mathrm{W})$.

$\mathrm{TF}(\mathrm{mg} / 100 \mathrm{~g})=(\mathrm{A} 374 \times \mathrm{V} \times$ 100) / $(76.5 \times \mathrm{W})$.

Where $\mathrm{V}=$ total volume extract in $\mathrm{ml}, \mathrm{W}=$ weight sample (in grams).

The calculation of the nutrient use efficiency was assessed according to (Baligar et al., 2001; Mosier et al., 2004; Dobermann, 2005). The nutrient use efficiency can be expressed by several agronomic indices such as agronomic efficiency (AE) in kg crop yield increase per kg of applied nutrient. These indices were calculated as follow: nitrogen use efficiency (NUE) was calculated according to the following equation.

NUE (mg sepals/mg $\mathrm{N})=$ (fresh sepals weight at applied $\mathrm{N} \mathrm{mg/pot)}$

(amount of nitrogen applied mg N/pot)

Agronomic efficiency of applied nitrogen (AEN) was calculated according to the equation:

$$
\begin{gathered}
\mathrm{AEN}(\mathrm{mg} / \mathrm{mgN})= \\
\frac{(\text { freshsepalsweightat appliedN mg/pot-freshsepalsweightatcontrohg/pot })}{(\text { amountof nitrogempliedmg N/pot })}
\end{gathered}
$$

\section{Data analysis}

The experimental design was Randomized Complete Block Design with four replicates. The Analysis of Variance (ANOVA) and Duncan multiple range tests at $5 \%$ level of probability were used to test the significance of differences between the treatments. Statistical data analyses were performed using Costat software (Steel and Torrie, 1986).

\section{Results and Discussion \\ Effect of fertilizer on the growth of roselle plants}

The data in (Table 3) show some growth parameters of roselle plants at full blooming and harvest stages. The recoded growth character including, fresh and dry biomass, plant height, root length, number of sepals and branches. Data showed that both of organic and inorganic fertilizers significantly $(P<0.05)$ increased the recoded growth parameters of roselle plants in the full blooming and harvest stages. The treatment of $50 \%$ urea $+50 \%$ compost increased the fresh and dry biomass, plant height, root length, number of sepals and branches by 156.84 , $135.37,95.00,76.05,191.11$ and $318.88 \%$ respectively above of con- 
trol. That is might be due to the increase in $\mathrm{N}$ content of the applied from urea fertilizer. This is in agreement with (Ojetayo et al., 2011 and Okunlola and Adeona, 2016) who observed an increase in the growth parameters with applied fertilizer types, which might be due to the effective use of applied fertilizer at this rate by the plants. Also, the presence of other nutrient elements like $\mathrm{P}$ in the organic fertilizer used seems to increase the absorption of $\mathrm{N}$ which promotes vegetative reproduction (Jones et al., 1991). The results may be due to the role of NPK in forming important molecules of phospholipids, nucleotides, nucleic acid and certain coenzymes, which play an important role in plant metabolism and thus increased growth thus was confirmed by (Kadu et al., 2009 and Hassan et al., 2015). Organic manure usually enhances seedling growth and plant development and increases productivity of a wide variety of crops (Canellas et al., 2000). The humic materials of organic manure produced auxin-like effects on plants (Muscolo et al., 1999).

Table 3. Effect of organic and inorganic treatments on the growth of roselle plants (at blooming stage)

\begin{tabular}{|c|c|c|c|c|c|c|}
\hline Treatments & $\mathbf{F W}$ & $\mathbf{D W}$ & $\mathbf{P H}$ & $\mathbf{R L}$ & $\mathbf{N S}$ & $\mathbf{N B}$ \\
\hline C & $195.1^{\mathrm{e}}$ & $45.8^{\mathrm{e}}$ & $70.0^{\mathrm{e}}$ & $14.2^{\mathrm{c}}$ & $9.0^{\mathrm{e}}$ & $9.0^{\mathrm{e}}$ \\
\hline $\mathrm{T} 1$ & $371.1^{\mathrm{c}}$ & $75.5^{\mathrm{c}}$ & $113.6^{\mathrm{c}}$ & $25.0^{\mathrm{a}}$ & $16.3^{\mathrm{c}}$ & $22.2^{\mathrm{c}}$ \\
\hline $\mathrm{T} 2$ & $322.8^{\mathrm{d}}$ & $67.5^{\mathrm{d}}$ & $98.3^{\mathrm{d}}$ & $20.0^{\mathrm{b}}$ & $13.0^{\mathrm{d}}$ & $18.0^{\mathrm{d}}$ \\
\hline $\mathrm{T} 3$ & $437.8^{\mathrm{b}}$ & $95.6^{\mathrm{b}}$ & $127.0^{\mathrm{b}}$ & $25.0^{\mathrm{a}}$ & $21.2^{\mathrm{b}}$ & $32.0^{\mathrm{b}}$ \\
\hline $\mathrm{T} 4$ & $501.1^{\mathrm{a}}$ & $107.8^{\mathrm{a}}$ & $136.5^{\mathrm{a}}$ & $25.0^{\mathrm{a}}$ & $26.2^{\mathrm{a}}$ & $37.7^{\mathrm{a}}$ \\
\hline
\end{tabular}

$\mathrm{FW}=$ fresh weight $\left(\mathrm{g} \mathrm{plant}^{-1}\right), \mathrm{DW}=$ dray weight $\left(\mathrm{g} \mathrm{plant}^{-1}\right), \mathrm{PH}=$ plant high $(\mathrm{cm}), \mathrm{RL}=$ root length $(\mathrm{cm})$, $\mathrm{NS}=$ number of sepals $/$ plant, $\mathrm{NB}=$ number of branch/plant, $\mathrm{C}=$ control, $\mathrm{T}_{1}=$ urea, $\mathrm{T}_{2}=$ compost, $\mathrm{T}_{3}=75 \%$ Urea $+25 \%$ compost, $\mathrm{T}_{4}=50 \%$ urea $+50 \%$ compost.

The data were collected at the blooming stage.

\section{Effect of organic and inorganic treatments on some photosynthetic pigments}

Figure 1 present the effect of organic and inorganic fertilizers on the leaf pigments content. As can be seen, the results indicated significant increases in the content of most pigments with increasing $\mathrm{N}$-fertilizer dose. However, the impact differs between the various pigments and depends on the combination of $\mathrm{N}$ levels in the fertilizer dose. Most of the treatments were significant whether they were added to mineral fertilizers alone or mixed with organic fertilizers. The best treatments for chloro- phyll A were $T_{3}$, chlorophyll $B$ was $\mathrm{T}_{1}$, while total chlorophyll was $\mathrm{T}_{1}$ and $\mathrm{T}_{3}$ together. The proportion of chlorophyll A+ B increased by 66, 16 and $61.77 \%$ compared with control. This may be due nitrogen is a structural element of chlorophyll and protein molecules, and it thereby affects the formation of chloroplasts and accumulation of chlorophyll in them (Tucker, 2004; Daughtry et al., 2000). Also N-fertilizer enhanced chlorophyll and carotenoid contents of spinach (Okunlola and Adeona 2016). These results are in agreement with Shah et al. (2017). The humic substances in organic manure were 
responsible for the increased chlorophyll contents observed in plants receiving the treatment, which might increase in plant photosynthesis and therefore increase in yield attributes (Tejada et al., 2008).

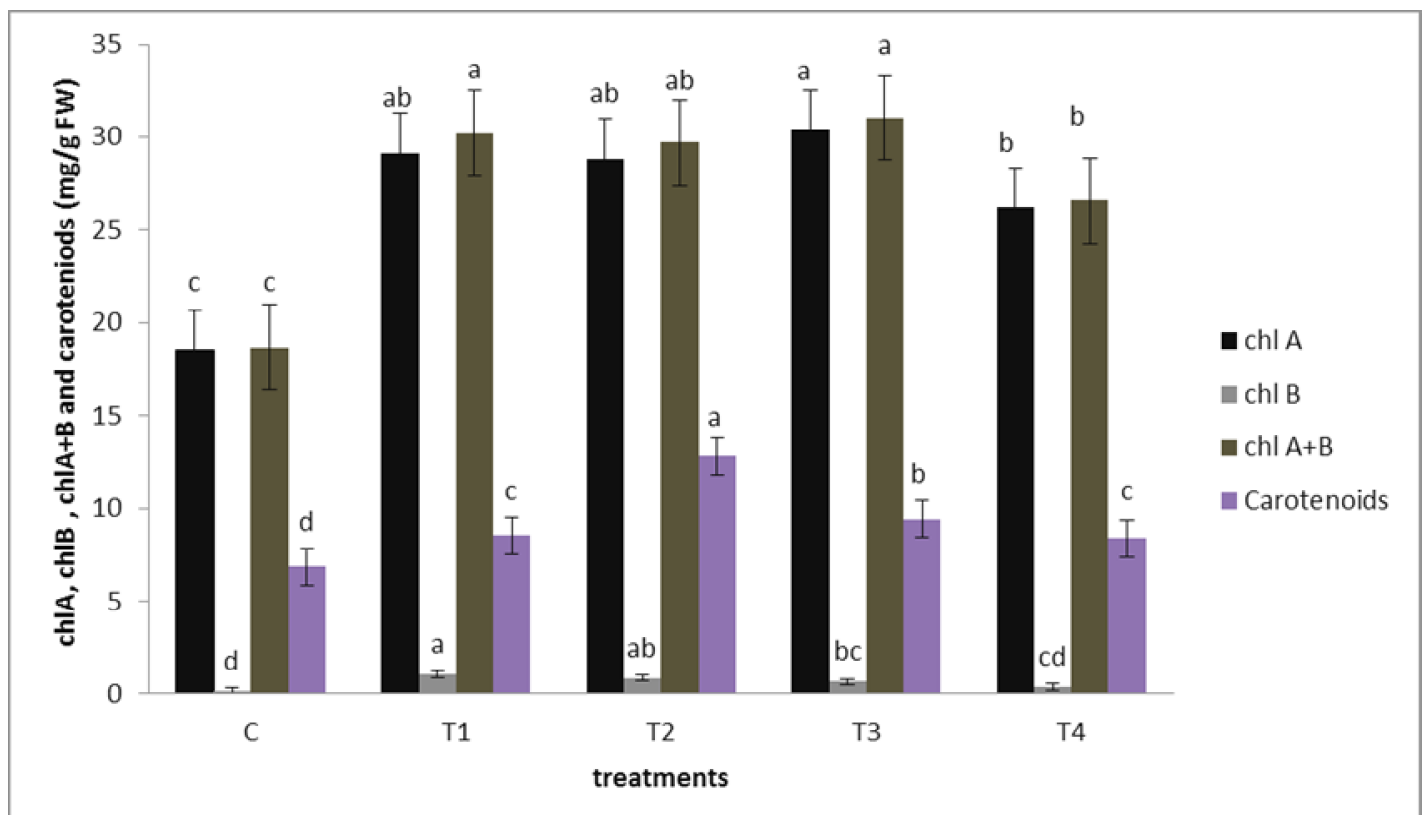

Figure 1. Effect of organic and inorganic fertilizer treatments on some photosynthetic pigments of roselle plants

Chl A= chlorophyll A, Chl B= chlorophyll $\mathrm{B}, \mathrm{Chl} \mathrm{A}+\mathrm{B}=$ chlorophyll $\mathrm{A}$ and $\mathrm{B}$.

The data were collected at the full blooming stage.

Effect of organic and inorganic treatments on nitrogen $(\mathrm{N})$, phosphorus (P) and potassium (K) uptake by roselle plants

The effect organic and inorganic fertilizer treatments on the uptake of $\mathrm{N}, \mathrm{P}$ and $\mathrm{K}$ were investigated at the full blooming stage (Figure 2 and 3). Figure showed that both of mineral and organic fertilizer application were significantly $(P<0.05)$ increased the $\mathrm{N}, \mathrm{P}$ and $\mathrm{K}$ concentration at the full blooming stage. Concerning the effect of different fertilization treatments at a full blooming stage, $\mathrm{N}, \mathrm{P}$ and $\mathrm{K}$ concentrations were increased by $357.92,182.25$ and $67.85 \%$ in $\mathrm{T}_{4}, \mathrm{~T}_{2}$ and $\mathrm{T}_{1}$ respectively, while the uptake was increased by $936.36,420$ and $352.83 \%$ in $\mathrm{T}_{4}, \mathrm{~T}_{4}$ and $\mathrm{T}_{3}$ respectively as compared with un-fertilizer plants. The obtained results indicate that the contents of those macro elements were significantly increased in plants. The highest N, P and K contents were obtained with organic amendments applied alone or in combination with $\mathrm{N}$ fertilizer. The highest $\mathrm{N}$ concentration was recorded with $\mathrm{T}_{4}$, This could be attributed to a higher $\mathrm{N}$ and $\mathrm{P}$ content of the organic amendments and a slow and sustained availability of the nutrients as observed by several workers in mints plant (Chand et al., 2001), in basil plant (Anwar et al., 2004). Also the compost was very rich in NPK contents this could explain the increase 
of these elements in the plants treated by this compound, which agree with the results of (Aziz et al., 2007 and Ahmed et al., 2011). The highest $\mathrm{P}$ and $\mathrm{K}$ concentration was recorded with $\mathrm{T}_{1}(100 \%$ urea), this may be due the application of phosphorus and po- tassium fertilizer would lead to increased phosphorus and potassium content in soil and would increase its concentration in plants. This result is in agreement with (Himawati et al., 2018 and Akhtar et al., 2019).

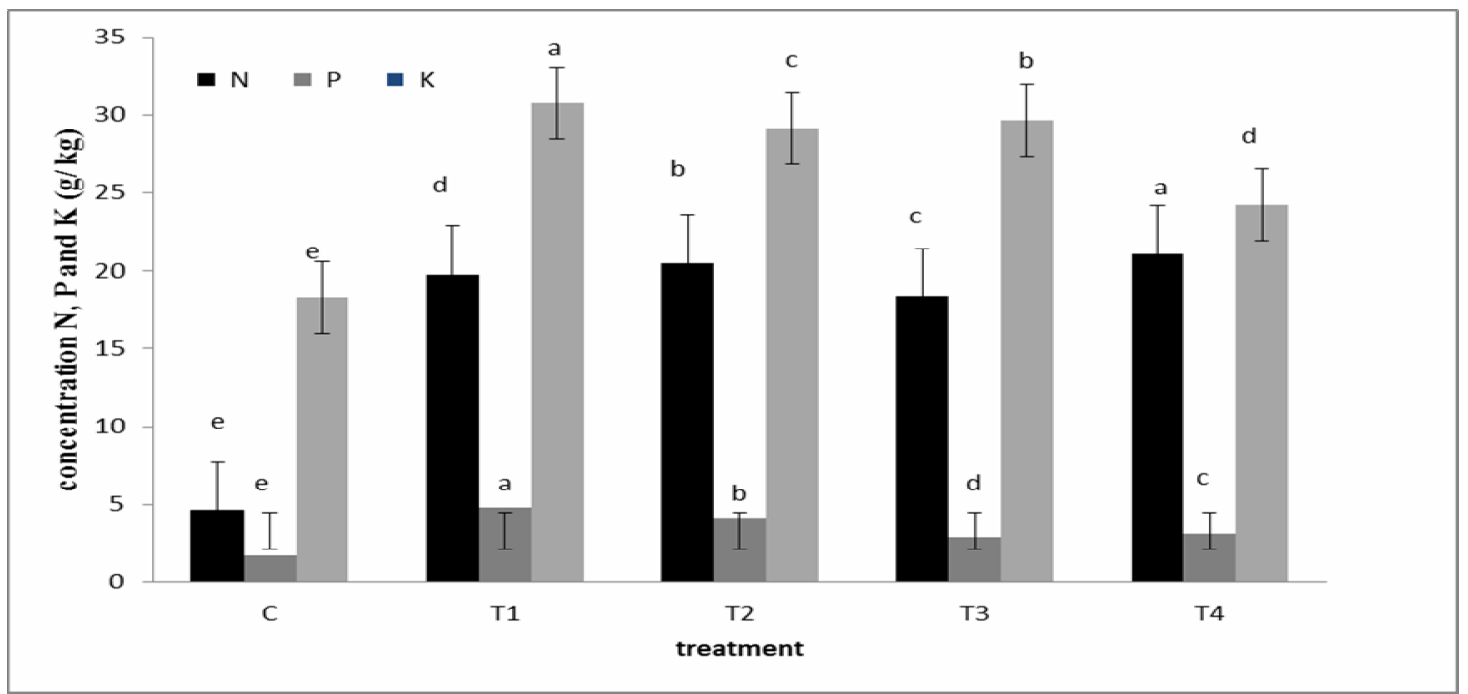

Figure 2. Effect of organic and inorganic treatments on N, P and K by roselle plants

The data were collected at the full blooming stage.

Means denoted by different letters are significantly difference according to Duncan's test at $\mathrm{P}<0.05$.

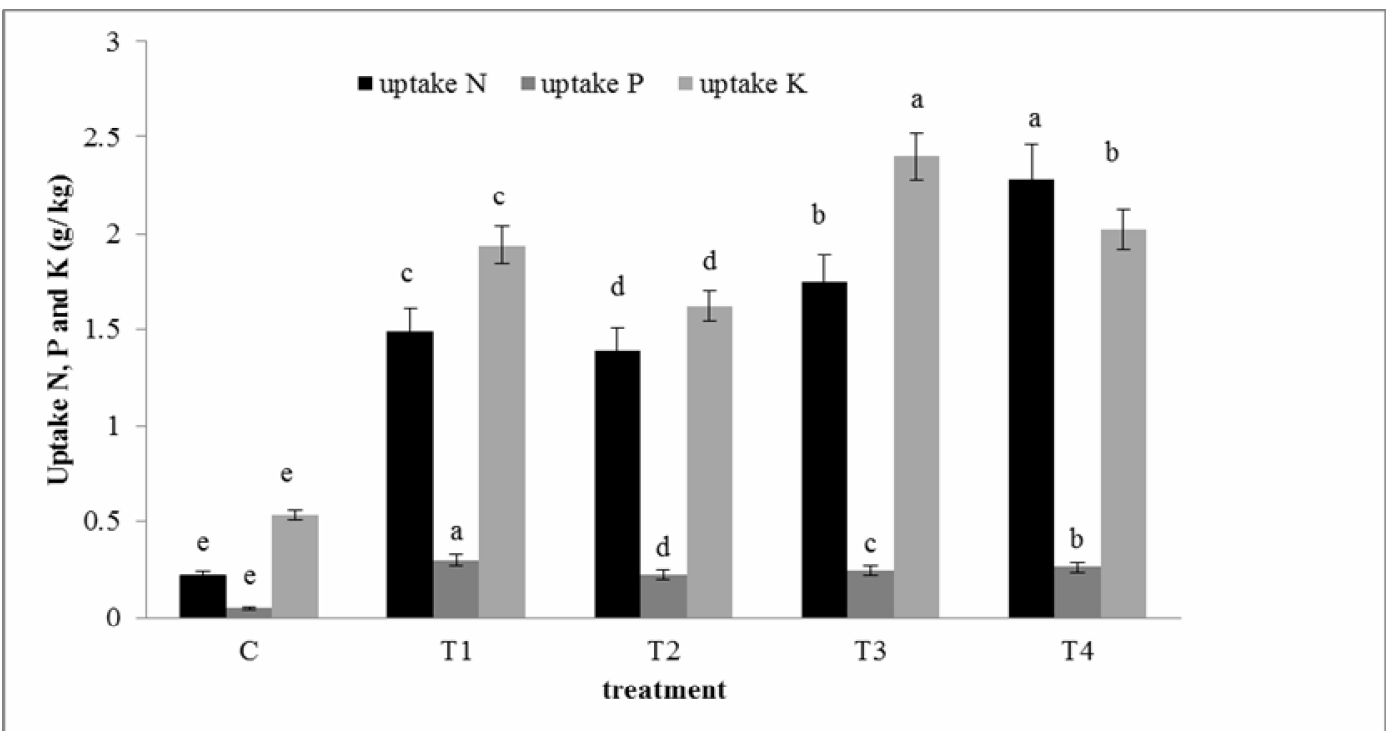

Figure 3. Effect of organic and inorganic treatments on N, P and K uptake by roselle plants

The data were collected at the full blooming stage.

Means denoted by different letters are significantly difference according to Duncan's test at $\mathrm{P}<0.05$. 


\section{Effect of organic and inorganic treatments on some soil chemical characteristics}

Some soil properties i.e., $\mathrm{pH}$, $\mathrm{EC}, \mathrm{OM}$ as well as $\mathrm{N}, \mathrm{P}$, and $\mathrm{K}$ availability were studied after the harvesting of roselle plants and the data are presented in Table 4. The results indicated that a slight significant decrease in the soil $\mathrm{pH}$ values as result of organic amendments. The low $\mathrm{pH}$ was recorded with $\mathrm{T}_{2}(100 \%$ compost) by $5.18 \%$ compared with the un-fertilizer treatments. $\mathrm{pH}$ decreasing can be arranged according to their effect as follow $\mathrm{C}>\mathrm{T}_{4}>\mathrm{T}_{3}>\mathrm{T}_{1}>\mathrm{T}_{2}$. Benefits of compost amendments added to soil include $\mathrm{pH}$ depressing and faster infiltration rate due to enhancing soil aggregation (Liang et al., 2011). The decrease in soil $\mathrm{pH}$ in the organic amendment treatments might result from the release of organic acids and carbon dioxide $\left(\mathrm{CO}_{2}\right)$ into the soil during the decomposition of the manure (Meena et al., 2018). The production of aliphatic and aromatic hydroxyl acids as a result of decomposition of organic manure (FYM) could also result in complexing and exchangeable aluminum ions and thus decrease the $\mathrm{pH}$ of soil (Grewal et al., 1981).

The results indicated that the soil EC values were reduced as result of organic amendments. The highest EC was recorded with $\mathrm{T}_{4}$ by $59.09 \%$ compared with the un-fertilizer. Treatments can be arranged according to their effect on EC increasing as follow $\mathrm{T}_{4}>\mathrm{T}_{3}>\mathrm{T}_{1}>\mathrm{T}_{2}>\mathrm{C}$. This may be due composts application, such as high levels of soil-borne diseases suppression and removal of soil salinity (Sinha et al., 2009). It was noticed that most of all soil samples were found in normal category EC < $2 \mathrm{dS} / \mathrm{m}$ (Sing and Mishra 2012). The normal electrical conductivity may be ascribed to leaching of salts to lower horizons (Pathak, 2010 and Mahmoud et al., 2019).

The results indicated significant increase in soil organic matter (SOM) which was recorded in the soil of organic manure. The results of the study showed that application of organic manure, especially the composted is a better proposition than application of manure alone for higher (SOM), nutrient uptake, and quality of roselle, it can helped in building soil fertility in terms of soil nutrient availability and supply of microbial mediated $\mathrm{C}$ and $\mathrm{N}$ in soil. The high O.M was recorded with $\mathrm{T}_{2}$ and $\mathrm{T}_{1}$ by 153.7 and $83.33 \%$ compared with unfertilizer treatments may be due to organic $\mathrm{N}$ sources comparatively mineralized slowly than mineral $\mathrm{N}$ which resulted in improvement in soil organic matter (Shafi et al., 2012). Also, addition of organic matter result in higher crop growth and biomass addition due to leaf shedding and root biomass might have contributed to higher soil organic carbon content (Acharya et al., 1988 and Menna et al., 2018). Agreement with Aoyama et al. (1999) who observed that organic carbon addition through manure led to higher concentration of total carbon in dry sieved macroaggregates than in micro aggregate. Researchers observed that application of organic matter has an impact on the chemical, physical and biological properties of the soil. Organic matter 
of manure is considered a source of major plant nutrients such as N, P and $\mathrm{K}$ (Liang et al., 2011).

Available soil $\mathrm{N}$ was significantly, the increase in available soil $\mathrm{N}$ was recorded in the soil of $\mathrm{T}_{4}(50 \%$ Urea $+50 \%$ compost) by $270.43 \%$ compared with un-fertilizer treatment. This might be attributed to mineralization of organic matter and the residual effect of $\mathrm{N}$ sources which enhanced the $\mathrm{N}$ levels in soil (Shafi et al., 2012). Also nutrient contents of organic sources served as soil amendment for crops and provided appreciable quantities of $\mathrm{N}$, organic sources (poultry manure) effectively increased soil fertility, yield and nutrient content of crops (Shafi et al., 2012).

These results agree with those obtained by Sharif et al. (2013) who reported that available nitrogen of soil was improved when composts added to soil. Suhane (2007) applied $100 \mathrm{~kg}$ nitrogen fertilizers to soil, only $20-25 \mathrm{~kg}$ is available in soil to plants, while when applied with compost gave higher available $\mathrm{N}$ in soil to plants and showed that exchangeable potassium $(\mathrm{K})$ was over $95 \%$ higher in organic manure. The increase in total $\mathrm{N}$ might be due to the direct addition of $\mathrm{N}$ through organic manure to soil. Available phosphorus and potassium was significantly increased in most treatments in the soil. The increase in available soil $\mathrm{P}, \mathrm{K}$ was recorded in the soil of $\mathrm{T}_{2}(100 \%$ compost) by 152.63 and $44.36 \%$ respectively compared with un-fertilizer treatment. This may be due soils receiving organic matter improved the soil organic carbon (C), total N, P, and $\mathrm{K}$ status (Sim and Wolf, 1994 and Kaur et al., 2005). Organic N sources released nutrients slowly and contribute to the residual pool of organic $\mathrm{N}$ and $\mathrm{P}$ in the soil and reduce $\mathrm{N}$ leaching in soils (Shafi et al., 2012). Also, Atiyeh (2000) showed that applied compost to soil increased soil available potassium compared to the traditional organic fertilizers. The increase in available potassium in soil receiving organic manure applied alone than control status may be ascribed to the direct potassium addition in the potassium pool of the soil. The result is corroborated (Choudhary et al., 1997 and Shukla and Ruhal, 1978). The increase in Olsen-P in treatment receiving applied organic manure alone may be due to the release of organically bound $\mathrm{P}$ during decomposition of organic matter, solubilization of soil $\mathrm{P}$ by organic acids produced during decomposition of organic matter. Continuous application of organic manure also reduced the activity of polyvalent cations such as $\mathrm{Ca}, \mathrm{Fe}$, and $\mathrm{Al}$ due to chelation which in turn considered responsible for reduction in P-fixation (Gupta et al., 1988). The application of organic manure increased Olsen-P because of its $\mathrm{P}$ content, and possibly by increasing retention of $\mathrm{P}$ in soil. A positive effect of organic manure on $\mathrm{P}$ availability was also observed (Roy et al., 2001). 
Table 4. Effect of organic and inorganic treatments on some soil chemical characteristics after the harvesting of roselle plants

\begin{tabular}{|c|c|c|c|c|c|c|}
\hline Treatments & $\begin{array}{c}\mathbf{p ~ H} \\
\mathbf{( 1 : 2 . 5 )}\end{array}$ & $\begin{array}{c}\mathbf{E c} \\
\mathbf{( d s / m )}\end{array}$ & $\begin{array}{c}\mathbf{O M} \\
\mathbf{\%}\end{array}$ & $\begin{array}{c}\mathbf{N} \\
\mathbf{p p m}\end{array}$ & $\begin{array}{c}\mathbf{P} \\
\mathbf{p p m}\end{array}$ & $\begin{array}{c}\mathbf{K} \\
\mathbf{p p m}\end{array}$ \\
\hline $\mathrm{C}$ & $8.11^{\mathrm{a}}$ & $0.22^{\mathrm{d}}$ & $0.54^{\mathrm{c}}$ & $33.58^{\mathrm{d}}$ & $5.89^{\mathrm{c}}$ & $286.3^{\mathrm{c}}$ \\
\hline $\mathrm{T} 1$ & $7.88^{\mathrm{c}}$ & $0.28^{\mathrm{c}}$ & $0.99^{\mathrm{b}}$ & $80.32^{\mathrm{b}}$ & $9.71^{\mathrm{b}}$ & $350.1^{\mathrm{b}}$ \\
\hline $\mathrm{T} 2$ & $7.69^{\mathrm{d}}$ & $0.24^{\mathrm{bc}}$ & $1.37^{\mathrm{a}}$ & $70.28^{\mathrm{c}}$ & $14.88^{\mathrm{a}}$ & $413.3^{\mathrm{a}}$ \\
\hline $\mathrm{T} 3$ & $7.92^{\mathrm{bc}}$ & $0.29^{\mathrm{b}}$ & $0.94^{\mathrm{b}}$ & $115.99^{\mathrm{a}}$ & $8.99^{\mathrm{b}}$ & $344.1^{\mathrm{b}}$ \\
\hline $\mathrm{T} 4$ & $7.95^{\mathrm{b}}$ & $0.35^{\mathrm{a}}$ & $0.90^{\mathrm{b}}$ & $124.39^{\mathrm{a}}$ & $8.93^{\mathrm{b}}$ & $337.5^{\mathrm{b}}$ \\
\hline
\end{tabular}

The data were collected at plant harvest.

Means denoted by different letters are significantly difference according to Duncan's test at $\mathrm{P}<0.05$.

Effect of organic and inorganic treatments on total yield and quality of roselle sepals

Figure 4 shows the effect of fertilization treatment's on the fresh and dry weight of sepals. This figure showed that both of organic and inorganic fertilizers significantly $(\mathrm{P}<0.05)$ increased the recoded growth parameters of roselle plants at the harvest stages. The treatment of $100 \%$ compost increase fresh weight and dry weight of sepals by 228.54 and $138.96 \%$ above the un-treated plants. This may be attributed to the release of nutrients to soil slowly for longer duration after decomposition resulting in better plant growth and yield. Also the role of nitrogen in en- hancement meristematic activity and cell division, consequently enhance yield (Lawlor, 2002). These results are in agreement with those reported by (Cupina et al., 2011, Anfinruda et al., 2013 and Abo-Zeid et al., 2017). Similar observation had been reported by Akanbi, (2002) on okra and maize, Stefano et al. (2004) on tomato and Akanbi et al. (2009) on roselle. The yield advantage on application of organic sources of nutrients was due to addition of micronutrients (Manna et al., 2005; Banik et al., 2006) along with the major nutrients, increased nutrient absorption capacity due to the higher root density. It also improved soil physical properties (Boparai et al., 1992).

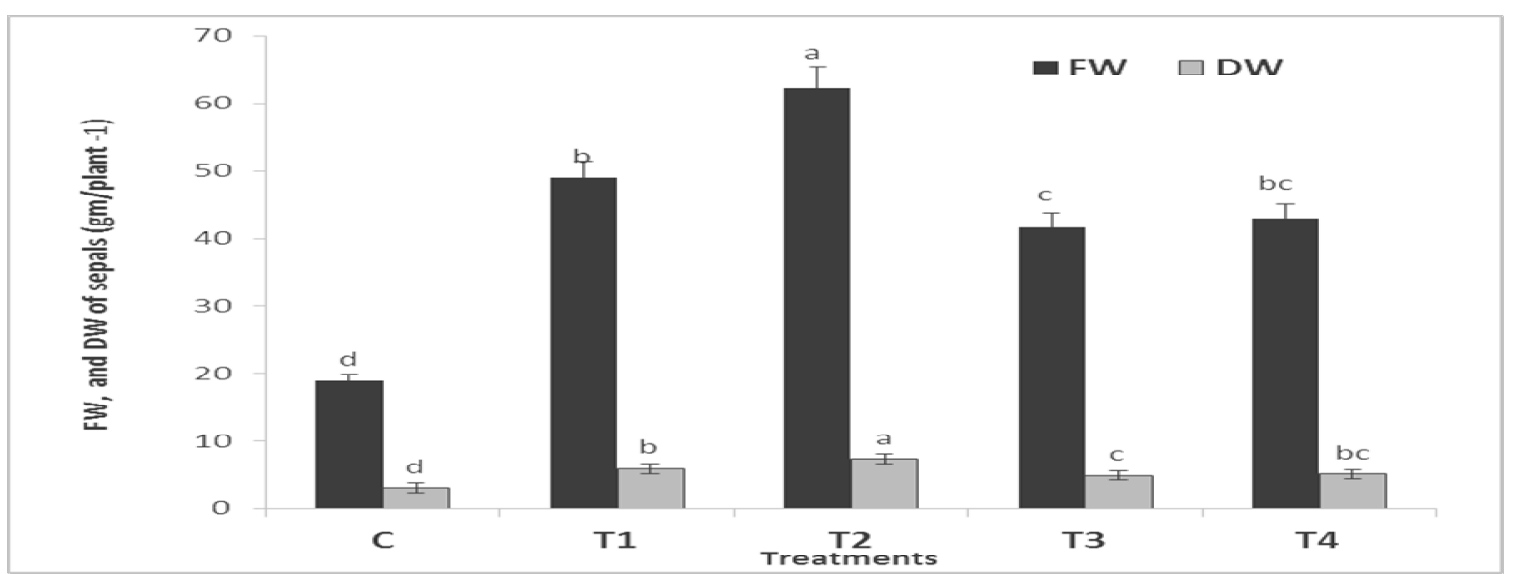

Figure 4. Effect organic and inorganic treatments on fresh and dry weight of sepals

$\mathrm{FW}=$ fresh weight of sepals $\left(\mathrm{g} \mathrm{plant}^{-1}\right), \mathrm{DW}=$ dry weight sepals $\left(\mathrm{g}\right.$ plant $\left.{ }^{-1}\right)$.

The data were collected at plant harvest.

Means denoted by different letters are significantly difference according to Duncan's test at $\mathrm{P}<0.05$. 
Anthocyanin pigments play many roles in plants, including providing protection against biotic and abiotic stresses (Middleton, 1986). Anthocyanins are pigments in the flavonoid family of phenylpropanoid compounds that are responsible for the blue, purple, and red colors of leaves, flowers and fruits (Middleton, 1986). As dietary components they also have beneficial effects on human health as they provide a source of an- tioxidants, reduce the incidence of coronary heart disease and exhibit anticancer activity (Koes, 2005). Figure, 5 shows the effect of fertilization on the anthocyanin and total flavonol. The fertilizer with significantly $(\mathrm{P}<0.05)$ increased the anthocyanin and flavonol in $\mathrm{T} 2$ by 71.46 and $75.01 \%$ above the untreated plants. Similar results on roselle obtained (Abbas and Ali, 2011 and Soha and Rabia, 2014).

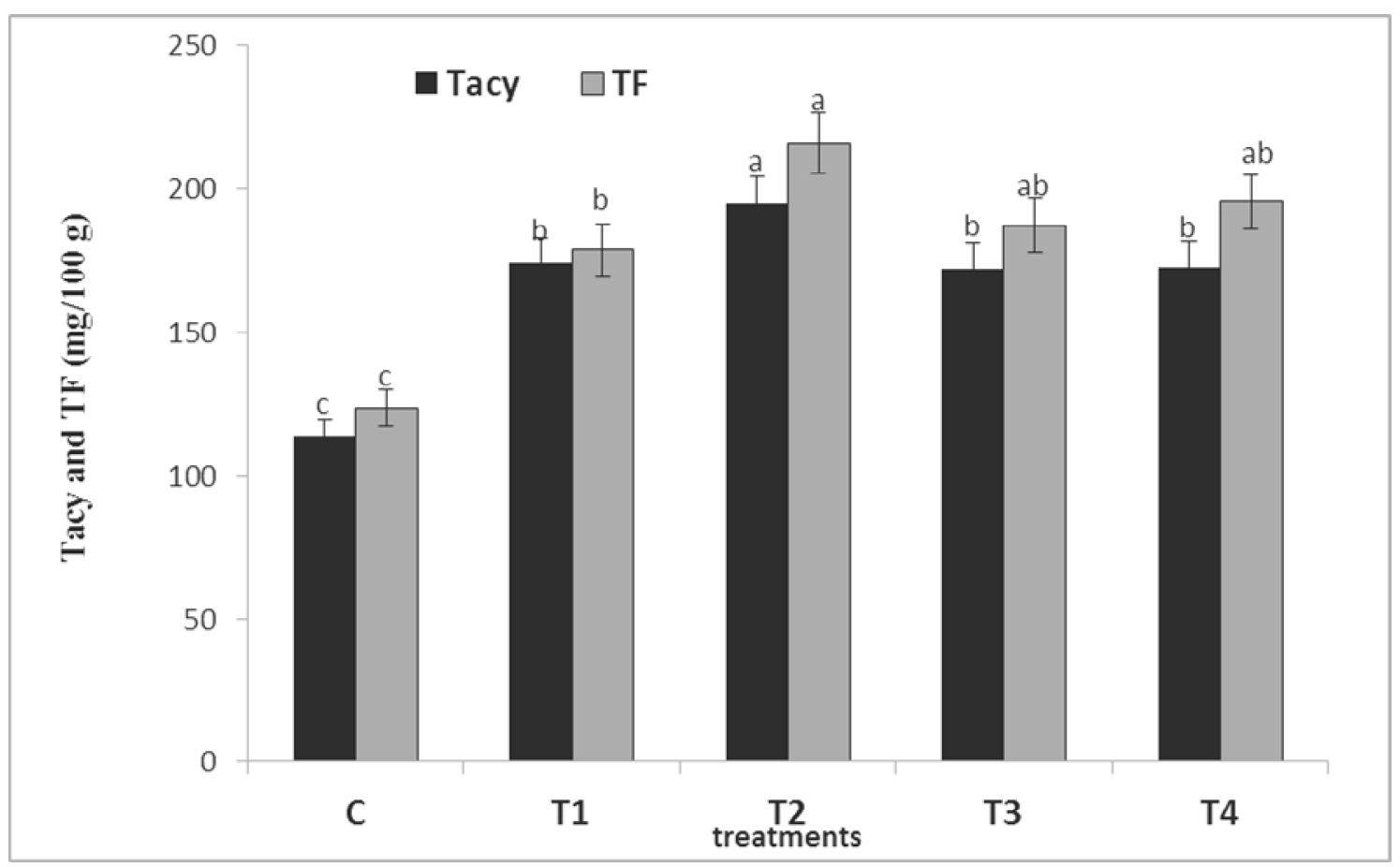

Figure 5. Effect of organic and inorganic treatments on quality of roselle sepals

$\mathrm{TAC}=$ total anthocyanin and $\mathrm{TF}=$ total flavonol.

The data were collected at plant harvest.

Means denoted by different letters are significantly difference according to Duncan's test at $\mathrm{P}<0.05$.

\section{Effect organic and inorganic treat- ments on nitrogen use efficiency}

Synchronization of crop N requirement with $\mathrm{N}$ supplies improving $\mathrm{N}$ use efficiency. A crop's demand for $\mathrm{N}$ is firmly related to yield potential, which in turn is associated with $\mathrm{N}$ supply and crop management practices. In this study, different $\mathrm{N}$ appli- cation rates significantly increased NUE and in particular. The nitrogen use efficiency (NUE) by sepals significantly improved due to the application $100 \%$ compost compared to the control treatment (Figure 6). It increased from $28.04 \mathrm{mg}$ sepals $/ \mathrm{mg}$ $\mathrm{N}$ compared to the control treatment. The agronomic efficiency of the ap- 
plied nitrogen (AEN) was significantly improved with applying the $100 \%$ compost. It rose from $44.46 \mathrm{mg}$ sepals /mg N compared to the control treatment. Borlaug and Doswell (1994) stated that soil fertility is the single most important factor that limits crop yields and as much as $50 \%$ of the increase in crop yields worldwide during the twentieth century is due to the use of chemical fertilizers.
High or low crop yield in different parts of the world could be correlated to level of fertilizer use per unit of land. Or may be due have improve applied urea efficiency by preventing or suppressing the transformation of amide- $\mathrm{N}$ in urea to ammonium hydroxide and ammonium through the hydrolytic action of the enzyme urease (Trenkel 2010).

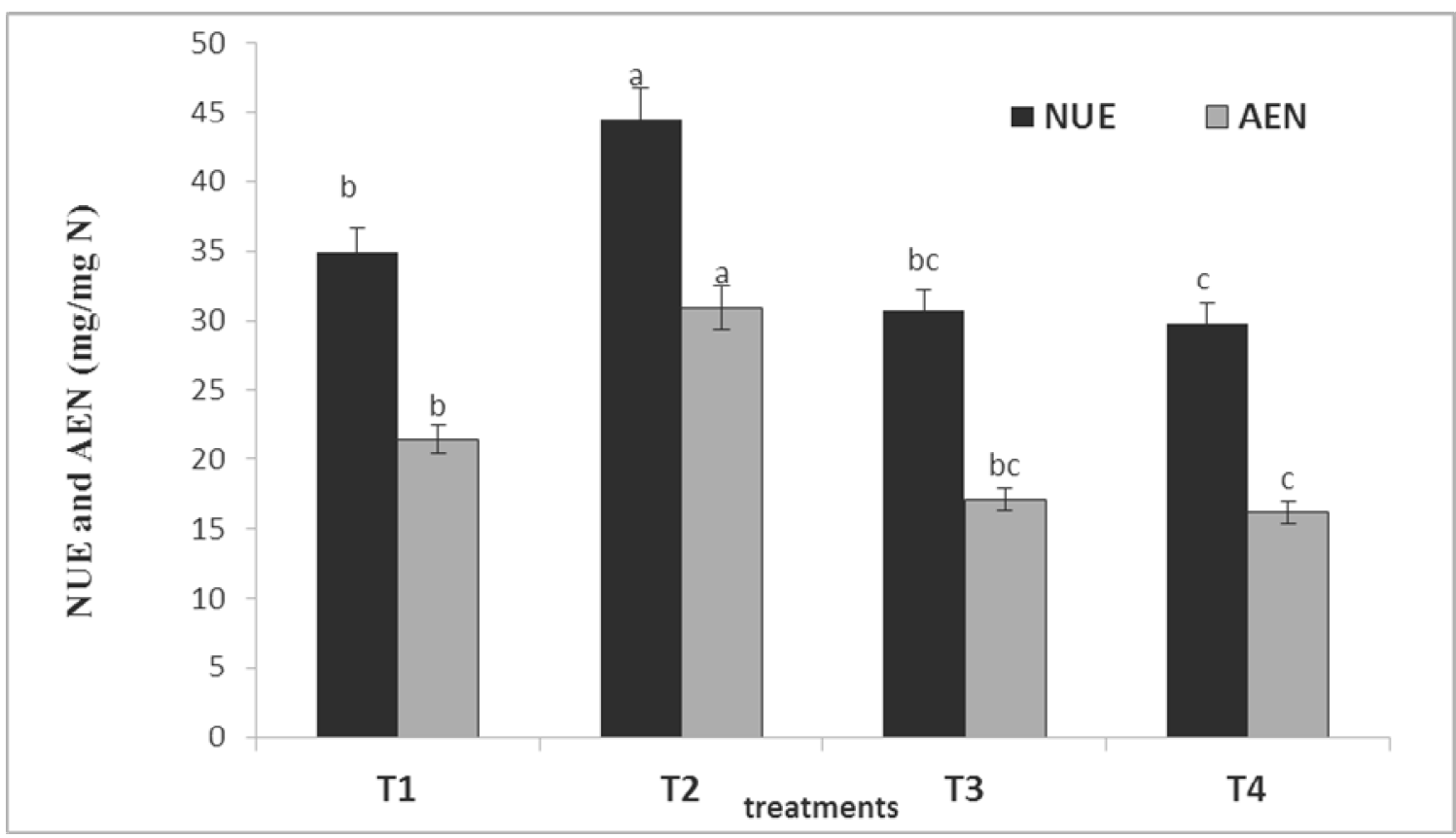

Figure 6. Effect organic and inorganic treatments on nitrogen use efficiency

NUE=nitrogen use efficiency (mg sepals/mg N), AEN= agronomic efficiency of the applied nitrogen ( $\mathrm{mg}$ sepals $/ \mathrm{mg} \mathrm{N}$ ).

The data were collected at plant harvest.

Means denoted by different letters are significantly difference according to Duncan's test at $\mathrm{P}<0.05$.

\section{Conclusion}

Generally it is concluded that roselle sepals yield and quality can be improved through the treatment of $100 \%$ composted and application of $50 \%$ urea $+50 \%$ compost improved the growth and yield of roselle also increased the available $\mathrm{N}$ nutrients in the soil as well as the macronutrients concentrations. The maximum yield and yield quality of sepals ware ob- tained from the treatment of $100 \%$ compost. Therefore, this treatment could be recommended to obtain economical yield with satisfactory quality and to improve the soil fertility under the conditions of the studied area.

\section{Acknowledgments}

The authors thank to Dr. Mamdouh A. Eissa, associated professor of soil and water Faculty of Agriculture, 
Assiut University Egypt for his supporting in setup of the experiment and preparing the final research paper.

\section{References}

Abbas, M.K. and A.S. Ali. 2011. Effect of foliar application of NPK on some growth characters of two cultivars of Roselle (Hibiscus sabdariffa L.). American Journal of Plant Physiology, 6(4): 22-227.

Abo-Zeid, S.T. Amal, L. Abd EL-Latif and S. 1shafey. 2017. Effect of Sources and Rates of Nitrogen Fertilizers on Forage Yield and Nitrate Accumulation for Sudangrass. Egypt. J. Soil Sci. 57(1): 23- 30.

Acharya, C. L., S. K. Bisnoi. and H.S. Yaduvanshi. 1988. Effect of longterm application of fertilizers and organic and inorganic amendments under continuous cropping on soil physical and chemical properties in an Alfisol. Indian J Agric. Sci. 58:509-516.

Ahmad, N. 1999. Fertilizer scenario in Pakistan. Policies and development. In: Proceedings of Conference on Agricultural and Fertilizer Use, pp. 15-16. Islamabad, Pakistan: NFDC, Division Government of Pakistan.

Ahmed,Y. M., E. A. Shalaby and Nermeen, T. Shanan. 2011. The use of organic and inorganic cultures in improving vegetative growth, yield characters and antioxidant activity of roselle plants (Hibiscus sabdariffa L). Afr. J. Biotechnol. 10(11): 1988-1996.

Akanbi, W.B., A. B. Olaniyan. A.O. Togun, A. E. O. Ilupeju and O.A. Olaniran. 2009. The Effect of organic and inorganic Fertilizer on Growth, Calyx Yield and Quality of Roselle (Hibiscus Sabdariffa L.).Am.- Eurasian J. Sustain. Agric., 3(4): 652-657.
Akanbi, W.B. 2002. Growth, Nutrient uptake and Yield of maize and okra as influenced by compost and Nitrogen fertilizer under different cropping systems. Ph.D. Thesis, University of Ibadan, Nigeria, pp: 228.

Akhtar, M., W. Ikram, T. Mahmood, S.Yousaf, S. M. W. Gillani and A. Ejaz. 2019. Improving soil phosphorus supply and wheat yield with manure-amended phosphate fertilizer. Experimental Agriculture, 1-11. Doi: 10.1017/ S0014479719000097.

Anwar, M., D. D. Patra, S. Chand, K. Alpesh, A. A. Naqvi and S. P. S. Khanuja. 2004. Effect of Organic Manures and Inorganic Fertilizer on Growth, Herb and Oil Yield, Nutrient Accumulation, and Oil Quality of French Basil. Communications in Soil Science and Plant Analysis, 36: 1737-1746.

Anfinruda, R., L. Cihacekb, B. L. Johnsona, Y. Jic and M. T. Bertia. 2013. Sorghum and kenaf biomass yield and quality response to nitrogen fertilization in the Northern Great Plains of the USA. Industrial Crops and Products, 50; 159-165.

Aoyama, M., D. A. Angers, A. N'dayegamiye and N. Bissonnette. 1999. Protected organic matter in water-stable aggregates as affected by mineral fertilizer and manure applications. Can. J Soil Sci. 79:419-425.

Atiyeh, R. M., N.Q. Arancon, C. A. Edwards and J.D. Metzger. 2000. Influence of earthworm-processed pig manure on the growth and yield of greenhouse tomatoes. Bioresour. Technol. 75, 175-180.

Aziz, E., N. Gad. and N. M. Badran. 2007. Effect of Cobalt and Nickel on Plant Growth, Yield and Flavonoids Content of Hibiscus sab- 
dariffa L. Aust. J. Basic Appl. Sci. 1(2): 73-78.

Baligar, V., N. Fageria and Z. He. 2001. Nutrient use efficiency in plants. Communications in Soil Science and Plant Analysis. 32, 921-950.

Banik, P., P. K. Ghosal, T.K. Sasmal, S. Bhattacharya, B. K. Sarkar and D. K. Bagchi. 2006. Effect of organic and inorganic nutrients for soil quality conservation and yield of rainfed low land rice in subtropical plateau region. J. Agron. Crop Sci. 192:331-343.

Baruah, T.C. and H.P. Barthakur. 1997. A text book of Soil Analysis, Vikas Publishing house PVT LTD, New Delhi.

Boparai, B. S., Y. Singh and B. D. Sharma. 1992. Effect of green manuring with Sesbania aculeata on physical properties of soil and growth of wheat in rice-wheat and maize-wheat cropping sequence in semiarid regions of India. Arid Soil Res. Rehabil. 6:135-143.

Borlaug, N. E. and C. R. Doswell. 1994. Feeding a human population that increasingly crowds a fragile planet $15^{\text {th }}$ World Cong. of Soil Sci. Acapulco, Mexico. Supplement to Trans. 10p.

Canellas, L. P., F. Olivares, A. L. Okorokova and A. R. Facanha. 2000. Humic acids isolated from earthworm compost enhance root elongation, lateral root emergence, and plasma $\mathrm{H}+-$ ATPase activity in maize roots. Plant Physiol. 130, 1951-1957.

Chand, S., M. Anwar and D. D. Patra. 2001. Influence of Combined Application of Farmyard Manure (FYM) and Inorganic Fertilizer on Herb, Essential Oil Yield and Nutrient Accumulation in Menthol Mint (Mentha arvensis). Journal of Medicinal and Aromatic Plant Sciences, 23: 29-33.
Chaudhary, N. R., A. K.Vyas and A. K. Singh. 1997. Growth and nutrient uptake in wheat influenced by nitrogen phosphorus and Zinc fertilization. Annuals of Agricultural Research; 18(3): 365-366 FAO. 2012. Annual report.

Chewonarin, T., T. Kinouchi., T and K. Kataoka. 1999. Effect of rosell (Hibiscus sabdariffa) a Thai medicinal plant, on the mutagenicity of various mutagens in Salmonella typhnumuriumand on formation of aberrant Crypt Foci induced by the colon carcinogens azoxymethane and 2-amino-1-methyl-6phenylimidazo [4,5-b] pyridine in F344 rats. Food and Chemical Toxicology; 37 (6):591】 601.

Cupina, B., M. Manojlović, D. Krstić, R. Ĉabilovski, A. Mikić, A. Ignjatović-Ćupina and P. Erić. 2011. Effect of winter cover crops on the dynamics of soil mineral nitrogen and yield and quality of Sudan grass (Sorghum bicolor L.) Moench. Australian J. of Crop Sci., 5(7): 839-845.

Daughtry, C. S. T., C. L.Walthall, M. S. Kim, E.B.C. Colstoun and E. J. E. McMurtrey. 2000. Estimating corn leaf chlorophyll concentration from leaf and canopy reflectance. Rem. Sens. of Environment. 74, 229-239.

Dobermann, A.R. 2005. Nitrogen use efficiency-State of the Art. Agronomy \& Horticulture - Faculty Publications. 316.

El Naim, A. M., A. I. Agwa, I. A. Khalid, S. M. Abdallateif and B. S.N. Eltayeb. 2017. Effects of nitrogen and bio-fertilizers on growth and yield of roselle (hibiscus sabdariffa var sabdariffa L.) International Journal of Agriculture and Forestry, 7(6): 145-150.

Grewal, J. S., R. C. Sharma and K. C. Sud. 1981. Effect of continuous 
application of $\mathrm{P} \mathrm{K}$ fertilizers and FYM on potato yield and some soil properties. J Indian Soc. Soil Sci; 29:129-131.

Gaur, A. C. 1982. Review of soil research in India. In: International Congress of Soil Science New Delhi, pp.278-305. New Delhi: International Society Soil Science.

Gupta, A. P., R. S. Antil and R. P. Narwal. 1988. Effect of farmyard manure on organic carbon, available $\mathrm{N}$, and $\mathrm{P}$ content of soil during different periods of wheat growth. J. Indian Soc. Soil Sci; 262:269-273.

Hassan, M. R. A., A. H. M. El-Naggar, E. H. Shaban and M. E. A. Mohamed. 2015. Effect of NPK and Bio-Fertilizers Rates on the Vegetative Growth and Oil Yield of Ocimum basillicum L. plants. Alexandria Science exchange journal, 36, (1); 58:72.

Himawati, S., B. H. Purwanto and S. N. H. Utami. 2018. Effect of organic fertilizer on kinetics of potassium release and rice uptake in inceptisols Kalitirto, Sleman. IOP Conf. Series: Earth and Environmental Science 215. doi:10.1088/17551315/215/1/01203.

Jackson, M.L., 1973. Soil chemical analysis Prentice-Hall, Inc. Englewood Cliffs, N. J. New Delhi, India.

Jones, J. B., W. Benjamin and A. M. Hary.1991. Plant Analysis Handbook; a practical sampling preparation analysis and interpretation guide micro - macro publishing Inc. USA. Pp $30-36$.

Kaur, K., K. K. Kapoor and A. P. Gupta. 2005. Impact of organic manures with and without mineral fertilizer. Soil Science 168: 117-122.

Kadu, A. P., P. R. Kadu and A.S. Sable. 2009. Effect of nitrogen, phosphorus and potassium on growth, flowering and bulb production in tuberose cv. single. J. Soil and Crops, 19(2), 367-370.

Koes, R., W.Verweij and F. Quattrocchio. 2005. Flavonoids: A colorful model for the regulation and evolution of biochemical pathways.Trends Plant Sci; 10: 236 242.

Lampe, S. 2000. Principal of integrated plant nutrition management system. In: Proceeding of Symposium on Integrated Plant Nutrition Management, pp. 3-17. Islamabad: NFDC.

Lawlor, D.W. 2002. Carbon and nitrogen assimilationin relation to yield: mechanisms are the key to understanding production systems. J. Exp. Botany, 53: 773-787.

Lee, D. H and F. J. Francis. 1971. Quantitative methods for Anthocyanins.VI Flavonols and Anthocyanins in cranberries.j.food Sci.36:1056-1060.

Liang, W., X.Wu, S. Zhang, Y. Xing and R.Wang. 2011. Effect of organic amendments on soil water storage in the aeolian sandy land of northeast China. Proceedings of the Electrical and Control Engineering (ICECE), International Conference on $16^{\text {th }}-18^{\text {th }}$ Sept. 2011. pp. 15381540 .

Lichtenthaler, H. K. 1987. Chlorophylls and carotenoids: pigments of photosynthetic biomembranes. In Methods in enzymology. 148 (34); 350-382. Academic Press.

Mahmoud, A. M., G. A. Elgharably, M. H. Rabie, H. M. Mohamed and M. A. Eissa. 2019. Evaluation of Soil Fertility Status in Toshka, Egypt: Available Micronutrients. World J. Agric. Sci., 15 (1): 01-06.

Meena, K. B., M. S. Alam, H. Singh, M. A. Bhat, A. K. Singh, A. K. Mishra and T. Thomas. 2018. Influence of farmyard manure and fertilizers on soil properties and yield and nutri- 
ent uptake of wheat. IJCS, 6(3): 386-390.

Manna, M.C., A.Swarup, R.H. Wanjari, H. N. Ravankar, B. Mishra, M.N. Saha, and P. A. Sarap. 2005. Longterm effect of fertilizer and manure application on soil organic carbon storage, soil quality and yield sustainability under sub-humid and semi-arid tropical India. Field Crops Res. 93(2-3): 264-280.

Middleton, E., C. Kandaswami. and J. Harborne. 1986. The flavonoids advances in research since. Chapman and Hall London. 1993; pp, 619-652.

Mohamed, N. E. 2012. Medicinal and Aromatic Crops in Egypt: A Study in Medical Geography. Journal of Educational and Social Research. 2 (9): 112-124.

Mostafa, A. M. 2016. The competitiveness of some non-traditional Egyptian exports, the symposium on the requirements of the Egyptian nontraditional agricultural export development, the Egyptian Society for Agricultura Economics, the High Institute of Marketing, Commerce and Information Systems, Al-AzharUniversity.

Mosier, A. R., J. K. Syers and J. R. Freney. 2004. Agriculture and the Nitrogen Cycle. Assessing the Impacts of Fertilizer Use on Food Production and the Environment. Scope-65. Island Press, London.

Mondal, N. K., J. K. Datta and A. Banerjee. 2015. Integrated effects of reduction dose of nitrogen fertilizer and mode of bio-fertilizer application on soil health under mung bean cropping system. Communications in Plant Science 5: 15-22.

Moroton, J. 1987. Roselle (Hibiscus sabdariffa L.) in fruits of warm climates, Julia, F. Morton, Miami) Florida. P. 281-286.
Muscolo, A., F. Bovalo, F. Gionfriddo and S. Nardi.1999. Earthworm humic matter produces auxin-like effects on Daucus carota cell growth and nitrate metabolism. Soil Biol. Biochem., 31: 13031311.

Naturland, E.V. 2004. Organic Farming in the Tropics and Subtropics Exemplary Description of 20 Crops. $1^{\text {st }}$ ed. Germany., p. 1] 22.

Nelson, W. L. 1982. Interaction of $\mathrm{k}$ with moisture and temperature. Potash Review, 1: 16-87.

Ojetayo, A.E., J.O. Olaniyi, W. B Akanbi and T. I. Olabiyi. 2011. Effect of fertilizer types on the nutritional quality of cabbage varieties before and after storage. Journal of Applied Biosciences, 48: 33223330.

Okunlola A. I. and A. P. Adeona. 2016. Effects of fertilizer types on the Growth, Yield and Pigment Concentration of Black Nightshade (Solanum Nigrum) in Southwestern Nigeria. International Journal of Research in Agriculture and Forestry 3(12); 12-16.

Olsen, S. R., C. V. Cole, F. S. Watanabe and L. A. Dean. 1954. Estimation of available phosphorus in soils by extraction with sodium bicarbonate. United States Department of Agriculture Circular 939, Washington, DC, $19 \mathrm{p}$.

Palhares, R. M., M. G. Drummond, B. S. A. Figueiredo, G.P. Cosenza., M. G. L. Brandão and G. Oliveira. 2015. Medicinal Plants Recommended by the World Health Organization: DNA Barcode Identification Associated with Chemical Analyses Guarantees Their Quality. PLOS One; 10(5):1-29.

Pathak, H. 2010. Trend of Fertility Status of Indian Soils, Current Advances in Agricultural Sciences, 2(1): 10-12. 
Rajasekaran, S., P. S. Moorthy and K. S. Ganesh. 2015. Effect of FYM, N, $P$ fertilizers and bio-fertilizers on germination and growth of paddy (Oryza sativa L.). International Letters of Natural Sciences 35: 5965.

Rao, P.U. 1996. Nutrient composition and biological evaluation of mesta seed. Plant foods for human nutrition. 49(1):27】 34.

Roy, S. K., R. C. Sharma and S. P. Trehan. 2001. Integrated nutrient management by using farmyard manure and fertilizers in potato sunflower-paddy rice rotation in the Punjab. J Agric. Sci; 137:271278.

Saeed, K. S., S. A. Ahmed, I. A. Hassan and N. J. Qader. 2015. Comparison of different levels of phosphate and bio-fertilizer of growth and yield on tomato (Lycopersicon esculentum Mill.) in green house condition. American-Eurasian Journal of Agricultural and Environmental Sciences 15: 210-215.

Shah, S. H., R. Houborg and M. F. McCabe. 2017. Response of Chlorophyll, Carotenoid and SPAD-502 Measurement to Salinity and $\mathrm{Nu}-$ trient Stress in Wheat (Triticum aestivum L.). Journal of Agronomy, 7, (61): 2:21. Doi: 10.3390/agronomy7030061.

Shafi, M., A. Shah, J. Bakht, M. Shah and W. Mohammad. 2012. Integrated effect of inorganic and organic nitrogen sources on soil fertility and productivity of maize. Journal of Plant Nutrition, 35:524537.

Sharif, M., T. Burni, F. Wahid, F. Khan, S. Khan, A. Khan and A. Shah. 2013. Effect of rock phosphate composted with organic materials on yield and phosphorus uptake of wheat and mung bean crops. Pak. J. Bot. 45 (4): 1349-1356.
Sharma, A. and O. P. Chaubey. 2015. Biotechnological approach to enhance the growth and biomass of Tectona grandis Linn. F. (Teak) seedlings. International Journal of Bio-Science and Bio-Technology 7: 19-28.

Shawky, M. E. 1967. Micro and macro pore-space distribution in profiles of typical Egyptian soils and factors affecting them. M.SC. Thesis, Fac. of Agric., Cairo Univ., A.R.E.

Shukla, U. C. D. S. and D. S. Ruhal. 1978. Effect of continuous application of farm yard manure and nitrogen on organic carbon and available $\mathrm{N}, \mathrm{P}$ and $\mathrm{K}$ content in soil. Ind. J Agric. Chem., 12:1118.

Sing, R. P and S. K. Mishra. 2012. Available macro nutrients (N, P, K and $\mathrm{S}$ ) in the soils of Chiraigon Block of District Varianasi (U.P). in relation to soils characteristics. Indian J. Sci. Res., 3 (1): 97-100.

Soha, E. Khalil and M. M. Rabia, Yousef. 2014. Study the effect of irrigation water regime and fertilizers on growth, yield and some fruit quality of Hibiscus sabdariffa L. International Journal of Advanced Research, 2, (5): 738-750.

Sim, J. T. and D. C. Wolf. 1994. Poultry waste management; Agricultural and environmental issues. Advanced Agronomy, 52: 2- 83.

Sinha, R. K., S. Herat., K.Chauhan and D. Valani. 2009. Earthworms vermicompost: a powerful crop nutrient over the conventional compost $\&$ protective soil conditioner against the destructive chemical fertilizers for food safety and security. American-Eurasian Journal of Agricultural and Environmental Science, 5(5): 14-22.

Stefano, P., R. Dris and F. Rapparini. 2004. Influence of growing conditions on yield and quality of 
cherry. II: Fruit quality. Journal of Food, Agriculture \& Environment, 2(1): 307-309.

Steel, R. G. D and J. H. Torrie. 1986. Principle and Procedure of statistics. A Biometrical Approach: $2^{\text {ed }}$ ed., McGraw- Hill Book Co. New York.

Suhane, R.K. 2007. Vermicompost (In Hindi); Pub. of Rajendra Agriculture University, Pusa, Bihar; pp: 88(www.kvksmp.org)

Tejada, M., J. L. Gonzalez, M. T. Hernandez and C. Garcia. 2008. Agricultural use of leachates obtained from two different vermicomposting processes. Bioresour. Technol., 99: 6228-6232.

Tandon, H.L. S. 1998. Organic Fertilizer and Bio Fertilizers. A Source
Book. New Delhi: Fertilizer Development and Consultation Organization.

Trenkel, M. 2010. Slow-and controlledrelease and stabilized fertilizers: an option for enhancing nutrient use efficiency in agriculture. Int'l Fertilizer Industry Association, Paris, France.

Tucker, M. 2004. Primary Nutrients and Plant Growth. In: Essential Plant Nutrients, North Carolina Department of Agriculture.

W.H.O (World Health Organization) 2011. The World Traditional Medicines Situation, in Traditional medicines: Global Situation, Issues and Challenges. Geneva 3:1-14. 
التأثير المتكامل لمصادر النيتروجين غير العضوية والعضوية على نمو و إنتاجية الكركليه

\section{(Hibiscus sabdariffa L.)}

حسن محمد السيد، صبرى امين حجاب، محمد أحمد يوسف، مصطفى يونس خلف الله قسم الآر اضى و المياه، كلية الزر اعة جامعة الآز هر - أسيوط ، مصر .

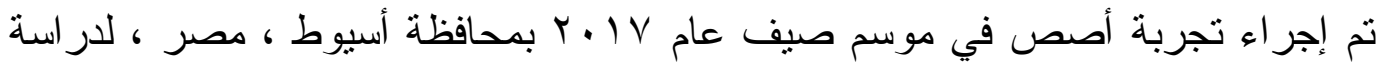

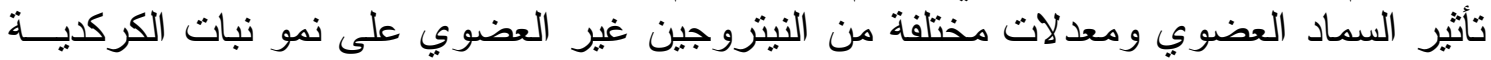

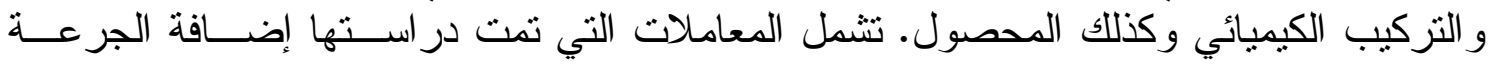

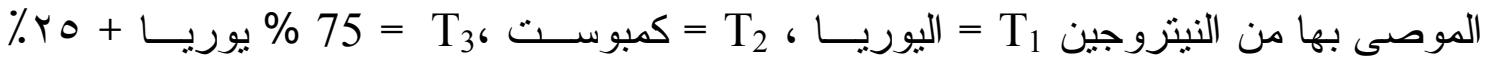

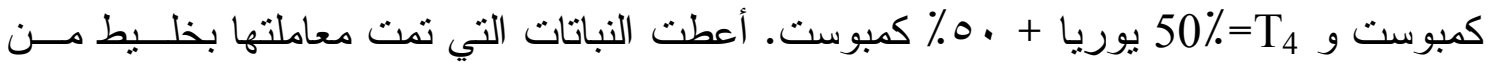

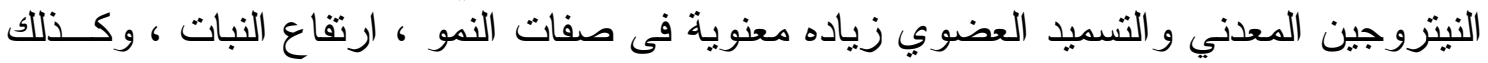

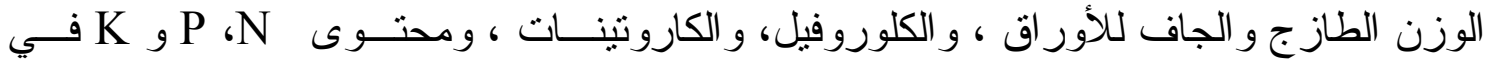

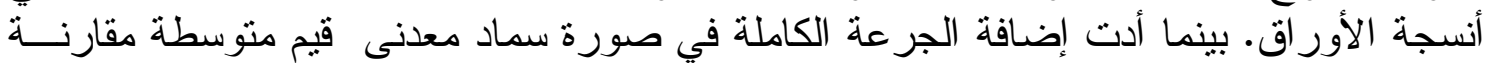

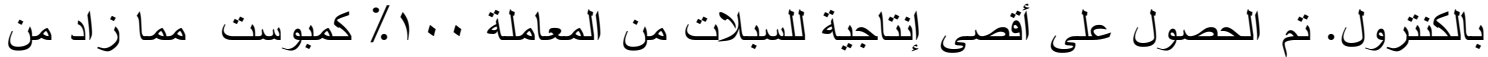

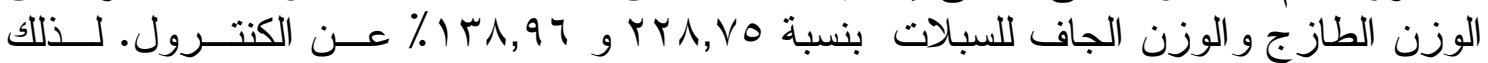

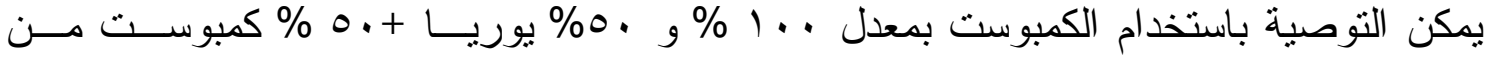

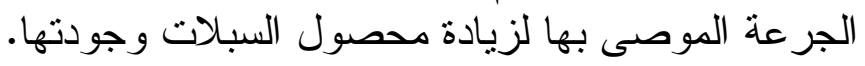
الكلمات المفتاحيةّ: بوريا، كمبوست، سبلات، كلوروفيل، كاروتينات. 